\title{
COMPATIBILITY STUDY OF FOUR BINARY COMBINATIONS OF ACTIVE INGREDIENTS FOR DERMAL FILM FORMING SYSTEMS
}

\author{
AURA RUSU ${ }^{1}$, ADRIANA CIURBA ${ }^{2}$, MAGDALENA BÎRSAN $^{3 *}$, PAULA ANTONOAEA $^{2}$, \\ BLANKA SZÉKELY-SZENTMIKLÓSI ${ }^{1}$, IBOLYA FÜLÖP ${ }^{4}$, GIORGIANA-ANDREEA PASCU ${ }^{5}$, \\ NICOLETA TODORAN ${ }^{2}$
}

\author{
${ }^{1}$ Pharmaceutical and Therapeutic Chemistry, Faculty of Pharmacy, "George Emil Palade" University of Medicine, Pharmacy, \\ Science and Technology of Târgu Mureş, Târgu Mureş, Romania \\ ${ }^{2}$ Pharmaceutical Technology and Cosmetology, Faculty of Pharmacy, "George Emil Palade" University of Medicine, Pharmacy, \\ Science and Technology of Târgu Mureş, Târgu Mureş, Romania \\ ${ }^{3}$ Pharmaceutical Technology, Faculty of Pharmacy, "Grigore T. Popa" University of Medicine and Pharmacy, Iassi, Romania \\ ${ }^{4}$ Toxicology and Biopharmacy, Faculty of Pharmacy, "George Emil Palade" University of Medicine, Pharmacy, Science and \\ Technology of Târgu Mureş, Târgu Mureș, Romania \\ ${ }^{5}$ Regulatory Affairs Department, Gedeon Richter România, Târgu Mureş, Romania
}

*corresponding author: magdalena.birsan@umfiasi.ro

Manuscript received: March 2020

\begin{abstract}
Adapalene (ADA), levofloxacin (LEV), meloxicam (MEL) and miconazole nitrate (MIC) were selected as potential active ingredients for film systems with dermal or transdermal delivery. This study aimed to evaluate the compatibility of four binary mixtures - ADA and LEV (M1), ADA and MIC (M2), LEV and MEL (M3), and LEV and MIC (M4) - combinations for new bioadhesive polymeric matrix dermal systems produced by the casting solvent evaporation technique. The Fouriertransform infrared spectroscopy (FTIR), differential scanning calorimetry (DSC) and molecular modelling (MM) were used to characterise and evaluate the compatibility between the selected active substances. In the FTIR data, M1, M2, and M4 mixtures presented a good compatibility. DSC revealed different chemical interactions as the temperature rose above $160^{\circ} \mathrm{C}$, especially for M3 and M4. Through MM technique, interactions were found on the M2 and M3 mixtures. Following the correlation of all obtained results, the best compatibility was found to be on M1 and M4 combinations.
\end{abstract}

\section{Rezumat}

Adapalenul (ADA), levofloxacina (LEV), meloxicamul (MEL) şi nitratul de miconazol (MIC) au fost selectate ca potenţiale ingrediente active în sistemele de tip film cu eliberare dermică sau transdermică. Scopul acestui studiu este de a evalua compatibilitatea a patru amestecuri binare - ADA şi LEV (M1), ADA şi MIC (M2), LEV şi MEL (M3), şi LEV şi MIC (M4) - combinaţii pentru noi sisteme dermice de tip matriţă polimerică bioadezivă produse prin tehnica de turnare şi evaporare a solventului. Pentru a caracteriza şi evalua compatibilitatea dintre substanţele active selectate au fost utilizate spectroscopia cu transformată Fourier (FTIR), calorimetria cu scanare diferenţială (DSC) şi modelarea moleculară (MM). Din datele FTIR, amestecurile M1, M2 şi M4 au fost compatibilite. DSC a arătat diferite interacţiuni chimice, în special pentru M3 şi M4, la temperaturi mai mari de $160^{\circ} \mathrm{C}$. Prin metoda $\mathrm{MM}$ au fost semnalate interacţiuni în combinaţiile M2 şi M3. Ca urmare a corelării tuturor rezultatelor obţinute, cea mai bună compatibilitate a fost găsită în combinaţiile M1 şi M4.

Keywords: dermal and transdermal therapeutic systems, infrared spectroscopy, differential scanning calorimetry, molecular modelling

\section{Introduction}

In healthcare, there is ongoing research for the development of new drug delivery systems, with release profiles that are able to improve the performance of the drug in terms of efficacy and safety. The classic topical forms are represented by ointments, emulsions and creams, products with conventional skin release. Significant innovation has occurred with the development of transdermal therapeutic systems - TTSs ("patches") as an attractive alternative to oral administration of drugs, discrete dosage forms that deliver the drug through the skin at a controlled rate to the systemic circulation (transdermal delivery). In the last decades, transdermal delivery has been and still is one of the most promising methods for the systemic delivery of drugs, being easy to administer and effective for the patient, which simultaneously improves the patient's compliance. Additionally, it is possible to associate different drugs in these easy-to-use devices. These aspects improve bioavailability, as they result in more uniform plasma levels, with a longer duration of action, which will reduce dose frequency [3]. Although transdermal therapy has real benefits for the patient, over the last four decades, the Food and Drug Administration (FDA) has only approved a small number of these 
products. Research in this field is continually expanding, with an increasing number of classes of substances being studied [88]. The development of these devices is focused on the quick and accurate release of active substances, controlled by physiological signals such as $\mathrm{pH}$, blood glucose level and enzyme activity [92]. The emergence of new forms of drug administration is dependent on the discovery of new methods to increase the skin permeability for macromolecules [46]. Thus, the production of TTSs is based on a number of physicochemical techniques such as lasers, microjets, electroporation, sonophoresis and iontophoresis, microneedles and use of chemical penetration enhancers $[35,57,74]$. Recently, in situ film-forming systems (on the skin, after spreading in a thin layer) - FFSs which form a film on the skin after spreading in a thin layer, have been developed as a new approach to be used as an alternative to both conventional and transdermal topical formulations [12]. In this paper, four pharmaceutical substances were selected as potential active ingredients (Figure 1) that could be useful in the form of film-forming systems with dermal and/or transdermal delivery: adapalene (ADA) [23, 84], levofloxacin (LEV) [36, 69], meloxicam (MEL) [16], and miconazole nitrate (MIC) [10]. These therapeutic agents have some significant physicochemical properties (Table I) based on which they can be individually used to treat various skin diseases: skin candidiasis, acne vulgaris, other skin infections, etc. [4, 8, 31, 78]. In the absence of any activation mechanism, penetration of the skin by the therapeutic agent released from the dermal delivery system is determined by its solubility and diffusivity through the stratum corneum [91], it depends on certain intrinsic properties of the molecule. For example, the aqueous solubility of a non-ionized organic compound is related to its octanol-water partition coefficient (P) [43], and is correlated with its melting point (MP) [62]. It is already known that a low MP will result in better absorption of the compounds [17]. Also, the diffusivity in stratum corneum is correlated with the molecular weight (MW); thus, the compound should not have high molecular weight and size $[16,62]$.

Table I

Physicochemical properties of selected compounds $[1,7,9,14,20,25,27,51,55,63,70,78,81]$

\begin{tabular}{|c|c|c|c|c|c|}
\hline $\begin{array}{c}\text { Compound/ } \\
\text { Therapeutical class }\end{array}$ & $\begin{array}{c}\text { MW } \\
(\mathrm{g} / \mathrm{mol})\end{array}$ & Solubility & $\mathrm{p} K_{\mathrm{a}}$ & $\log P$ & $\mathbf{M P}\left({ }^{\circ} \mathbf{C}\right)$ \\
\hline $\begin{array}{c}\text { ADA/ } \\
\text { Retinoids; NSAIDs }\end{array}$ & 412.52 & $\begin{array}{l}\text { Soluble in THF, DMSO and DMF, sparingly } \\
\text { soluble in ethanol, and practically insoluble in water }\end{array}$ & 4.23 & $\begin{array}{l}8.04 \\
8.60\end{array}$ & $319-322$ \\
\hline $\begin{array}{c}\mathbf{L E V} / \\
\text { Fluoroquinolones }\end{array}$ & 361.37 & $\begin{array}{c}\text { Freely soluble in glacial acetic acid, chloroform, } \\
\text { sparingly soluble in water }\end{array}$ & $\begin{array}{l}\text { (HA) } 5.59 \\
\left(\mathrm{BH}^{+}\right) 7.94\end{array}$ & 1.27 & $\begin{array}{l}225-227 \text { (with } \\
\text { decomposition) }\end{array}$ \\
\hline $\begin{array}{c}\text { MEL/ } \\
\text { NSAIDs }\end{array}$ & 351.4 & $\begin{array}{c}\text { Insoluble in water, soluble in DMF, very slightly in } \\
\text { methanol; } 1.736 \mathrm{M} \mathrm{x} 10^{-3} \text { (in } 0.2 \mathrm{M} \text { phosphate } \\
\text { buffer pH } 7.4 \text { at } 37^{\circ} \mathrm{C} \text { ) }\end{array}$ & $\begin{array}{l}\text { (HA) } 4.5 \\
\left(\mathrm{BH}^{+}\right) 3.05\end{array}$ & 2.71 & $257-260$ \\
\hline $\begin{array}{c}\text { MIC/ } \\
\text { Antifungals }\end{array}$ & 479.1 & $\begin{array}{l}\text { Very slightly soluble in water ( } 1 \text { in } 6250) \text { and iso- } \\
\text { propanol ( } 1 \text { in } 1408) \text {, slightly soluble in chloroform } \\
(1 \text { in } 525) \text { and ethanol ( } 1 \text { in } 312) \text {, sparingly soluble } \\
\text { in propylene glycol ( } 1 \text { in } 119) \text { and methanol ( } 1 \text { in } \\
75) \text {, freely soluble in DMSO }\end{array}$ & 6.7 & 5.96 & $178-184$ \\
\hline
\end{tabular}

Table II

Fulfilling the general requirements for selected drug candidates to be comprised in TTSs $[13,21,31,52,47,59$,

\begin{tabular}{|c|c|c|c|c|}
\hline Requirements & ADA & LEV & MEL & MIC \\
\hline $\mathrm{MW}<400$ & +- & + & + & - \\
\hline Log P 1.0 - 4 (octanol-water) & - & + & + & - \\
\hline Low MP $\left(<200^{\circ} \mathrm{C}\right)$ & + & -+ & - & - \\
\hline Low dose $(<20 \mathrm{mg} /$ day $)$ & + & - & +- & - \\
\hline Half-life $\leq 10$ hours & +- & + & - & - \\
\hline Non-irritating and non-sensitizing to the skin properties & +- & no data & no data & + \\
\hline Low oral bioavailability & + & - & +- & + \\
\hline
\end{tabular}

$78,86,87]$

Additionally, a series of other biopharmaceutical parameters are known to influence the selection of a drug candidate for passive skin penetration: dose, half-life, $\log \mathrm{P}$, skin permeability coefficient, oral bioavailability, therapeutic index, and non-irritating and non-sensitizing properties [33]. None of the substances studied in this work has all the intrinsic biopharmaceutical parameters to fulfil all the necessary conditions for transdermal penetration after skin application (Table II). Thus, their bio-distribution on/in the skin and deeper will also have to be modulated by 
extrinsic factors such as excipients, system structure and the biological variability.

Consequently, the factors that influence the release and level of activity of the drug into the skin depend not only on the intrinsic properties but also on the excipients and system structure and not least on the biological variability [62]. Moreover, combinations of these different drugs, which have different permeation pathways and mechanisms of action, could have better therapeutic outcomes than the drugs used individually, as evidenced by some published studies summarized below

Adapalene (ADA), like other retinoids, is considered by the Global Alliance on Improving Acne Outcomes as the first-line therapy in the treatment of acne, being recommended to be used either independently in cases of mild acne, or together with a broad-spectrum antibiotic in cases of other forms of acne. In this line, since 2011, several retinoids were investigated as combinations with classical topical antibiotics (clindamycin, erythromycin) [30]. Also, the new combination between ADA and nadifloxacin (a fluoroquinolone) was clinically and microbiologically evaluated in topical products for the treatment of acne [83].

Levofloxacin $(L E V)$, the pure levogire isomer of ofloxacin (a forerunner of nadifloxacin, recently introduced on a TTS device [42]), is used both systemically and topically [41, 49]. In addition to numerous ophthalmic formulations with LEV, other formulations such as emulsions, ointments, etc. have been studied [56-58]. In fact, LEV is currently widely used as an antibiotic for the skin and soft tissues. Due to the favourable results, LEV could be a candidate for insertion into binary TTSs, exhibiting much lower bacterial resistance than other antimicrobials [48, 66, 73]. Practically, ADA and LEV would be a unique combination of topical pharmaceutical preparations to be formulated.

Miconazole nitrate (MIC) is an antifungal used in many diseases, being known as a beneficial adjuvant in acne therapy, as a single compound or in combinations $[28,32]$. Its significant advantage is that it remains cumulative in the stratum corneum for up to 4 days after application [11, 56].

Thus, combining ADA with an antifungal, e.g. MIC, could potentially minimise complications of chronic acne. Furthermore, combinations could cumulate the antifungal effect of MIC and antimicrobial effect of LEV or anti-inflammatory effect of ADA, respectively. The combination of LEV with MIC could be considered optimal because the action of LEV is potentiated when is used with MIC $[18,65]$.

Meloxicam (MEL) belongs to the class of nonsteroidal anti-inflammatory drugs (NSAIDs) without any topical form present on the market. The cutaneous combinations could take advantage of the potential synergism between an anti-inflammatory (MEL, or ADA) associated with an antibiotic active on soft tissues (LEV), or an antifungal (MIC), thus being potentially useful for patients, without any known incompatibility issue [24, 39, 50].

The compatibility studies between the associated substances represent a compulsory stage in the formulation of TTSs (or FFSs) in form of bioadhesive polymeric matrix produced by the casting solvent evaporation technique [85] because they will interact at the molecular level both in the fusion stage based on dissolution of ingredients and in the evaporation of the solvent stage, during the formation of the dermal films. Therefore, as the first stage of preformulation studies, the aim of this study was to evaluate the chemical compatibility of four binary combinations of drugs ADA and LEV (M1), ADA and MIC (M2), LEV and MEL (M3), and LEV and MIC (M4) - using 2 methods: computational chemistry by molecular modelling analysis (MM), followed by correlation of the virtual results with the experimental data obtained by Fourier transform infrared (FTIR) spectroscopy and Differential scanning calorimetry (DSC) analysis, respectively.

\section{Materials and Methods}

MM - software and method

HyperChem ${ }^{\circledR}$ software (version 8, Hypercube Inc., USA) was used to compute, based on their known chemical structures and physicochemical properties, the chemical structures of the studied compounds (ADA, LEV, MEL, MIC) and then to establish their most stable conformation in binary mixture (M1-M4), both in the 1:1 molar ratio and in the $1: 1$ mass ratio (corresponding to the molar ratio of 7ADA/8LEV - M1, 7ADA/6MIC - M2, 1LEV/1MEL - M3 and 4LEV/ $3 \mathrm{MIC}-\mathrm{M} 4)$.

MM2 calculations were performed to evaluate the mechanical molecular compatibility of binary mixtures [40]. MM2 force field simulations in vacuum were carried out, using the Polak-Ribiere minimisation algorithm and 0.01 RMS gradients. The structures of the four pharmaceutical compounds were generated through SMILES (Simplified Molecular Input Line Entries), and the geometry of ADA, LEV, MEL, MIC and their four studied binary combinations were then minimised using the parameters mentioned above in Hyperchem. The binding energies (E) of the binary combinations were calculated using the equation (1):

$$
E_{\text {binding }}=E_{\text {complex }}-\left(E_{\text {compound } 1}+E_{\text {compound } 2}\right)
$$

where $E_{\text {binding }}$ represents the supposed binding energy between the two active ingredients, $E_{\text {complex }}, E_{\text {compound I }}$ and $E_{\text {compound } 2}$ represents the energy after minimisation is performed. Negative binding energy shows a thermodynamically favoured complex [40]. Chemicals, apparatus and analysis methods Selected compounds were purchased in the form of the reference standard, as follows: ADA, LEV and 
MIC from Sigma Aldrich, USA, and MEL from Techno Drugs \& Intermediates Ltd., India. Each of them was analysed individually and in binary combinations (M1-M4) prepared by mixing the compounds in a mass ratio of 1:1. The Fourier-transform infrared spectroscopy (FTIR) spectra were registered by FT/ IR-470Plus Jasco spectrometer, Japan, and processed using the Jasco Spectra Manager for Windows XP. The samples (binary mixture in 1:1 mass ratio) were prepared as $\mathrm{KBr}$ pellets in the range of $4000 \mathrm{~cm}^{-1}$ $600 \mathrm{~cm}^{-1}, 16$ scans at $4 \mathrm{~cm}^{-1}$ resolution. Differential Scanning Calorimetry (DSC) analysis was performed in a DSC 60 Shimadzu apparatus. The samples were weighted $(3 \mathrm{mg}$ ) (binary mixture in 1:1 mass ratio) and placed in aluminium crucibles. The DSC curves were registered in the range of $40-400^{\circ} \mathrm{C}$, with a temperature increase rate of $10^{\circ} \mathrm{C} / \mathrm{min}$, in an air atmosphere, using reference material.

\section{Results and Discussion}

Compatibility study by MM analysis

MM is a relatively new method to predict the compatibility of different substances for the screening on design pharmaceutical form and HyperChem, used in this study, is a software that offers quantum chemical calculations, molecular mechanics, and dynamics. Based on $\mathrm{E}$ binding values, it is possible to predict if combinations of two substances are (if $\mathrm{E}>0$ ) or are not (if $\mathrm{E}<0$ ) thermodynamically compatible [45, 58, $64,75,76,82,93]$.

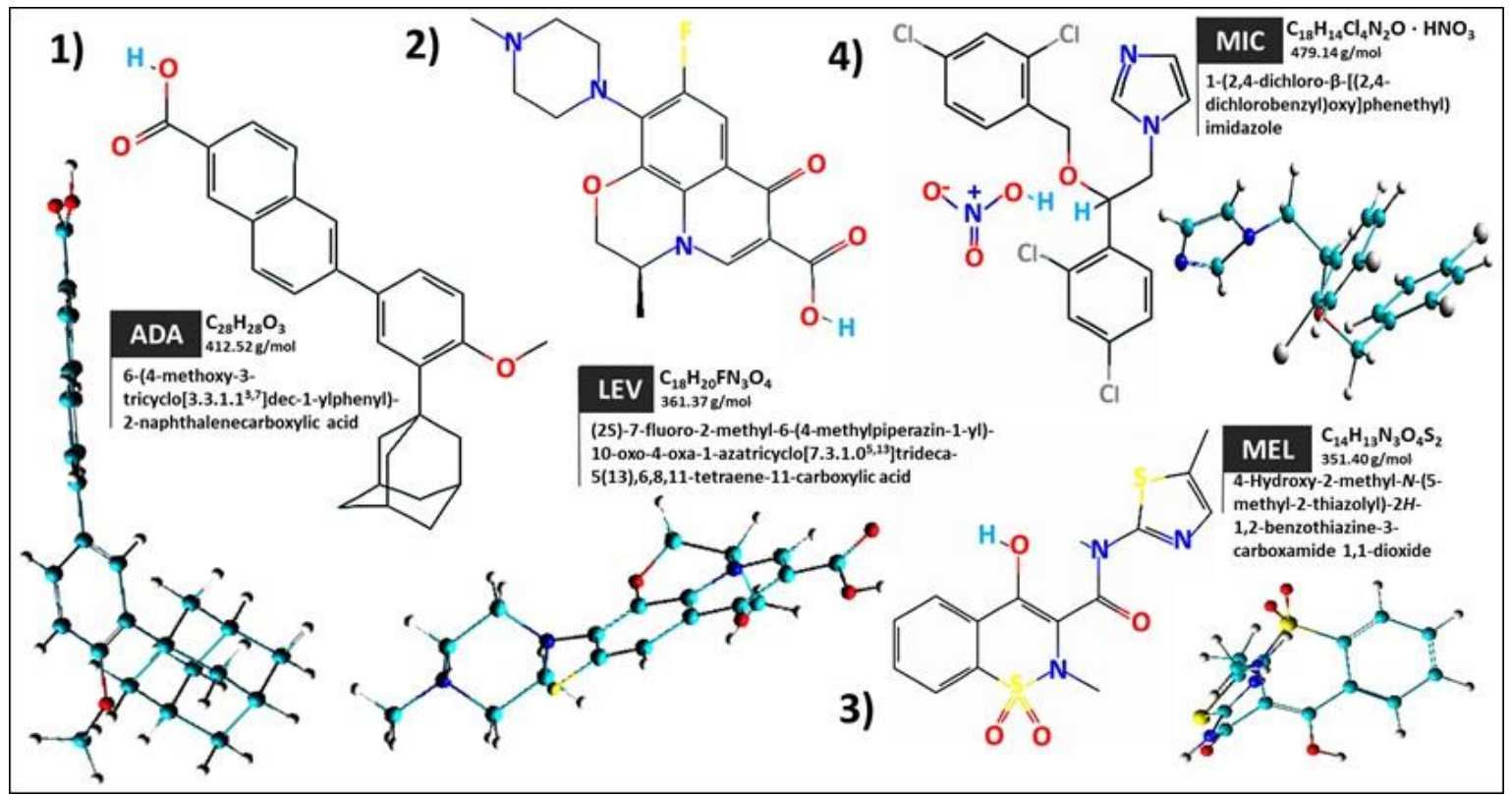

Figure 1.

Molecules of the studied compounds computed by MM, based on their known chemical structure: 1) Adapalene (ADA), 2) Levofloxacin (LEV), 3) Meloxicam (MEL), 4) Miconazole nitrate (MIC)

It was verified the molecular mechanics' compatibility between the associated compounds in the four studied mixture (M1-M4), calculations were performed for both 1:1 molar ratio - to identify the most favourable complex, and 1:1 mass ratio - the form in which the samples are usually prepared in experimental studies. The calculated values of E binding and the specific energies are shown in Table III.

Binary mixtures 1:1 molar ratio (Table III, a). The negative values of the binding energy predicted for M1 and M4 mixtures indicate that complexes were thermodynamically favoured between their two compounds (Figure 2). For M1 and M4 mixtures indicate that complexes formed between their two components were thermodynamically favoured. In the case of the M1 complex, the LEV molecule is situated close to the methoxyphenyl-naphthoic acid moiety of ADA, while on the M4 complex, the piperazinyl group of the LEV is oriented toward the imidazole group of the MIC. Consequently, based on the analysis of the detailed energy data, the drug-drug interactions were due to van der Waals and bond angle forces, with no hydrogenbonds being detected.

Binary mixtures 1:1 mass ratio (Table III, b). Forcing several molecules to approach by mechanical, spatial constraints cause thermodynamic changes, observed especially in the case of M2 (7ADA/6MIC mole ratio), case in which the value of $\mathrm{E}$ binding became negative due to the release of a very weak electrostatic energy. In the case of $\mathrm{M} 3$, the 1:1 molar ratio corresponds to a mass ratio of $1.027 \mathrm{LEV}$ : $0.93 \mathrm{MEL}$ which can be considered to be sufficiently close to the $1: 1$ mass ratio, given that it was not possible to adjust by 
FARMACIA, 2020, Vol. 68, 5

increasing the number of molecules in the computed

mixture.

Table III

The binding energies and the partial energies calculated for the most favourable complex

\begin{tabular}{|c|c|c|c|c|c|c|c|c|}
\hline \multirow{2}{*}{ Energies (kcal/mol) } & \multicolumn{4}{|c|}{ a) Molar ratio 1:1 } & \multicolumn{4}{|c|}{ b) Mass ratio 1:1 } \\
\hline & M1 & M2 & M3 & M4 & M1 & M2 & M3 & M4 \\
\hline Bond & 5.39 & 5.26 & 5.28 & 2.93 & 32.83 & 33.29 & 5.28 & 6.93 \\
\hline Angle & 4.37 & 24.45 & 51.52 & 20.51 & 39.93 & 136.77 & 51.52 & 61.04 \\
\hline Dihedral & 4.84 & -1.24 & 11.82 & 1.68 & 42.87 & -4.86 & 11.82 & 7.43 \\
\hline Van der Waals & 33.29 & 28.64 & 8.71 & 13.05 & 61.78 & 50.25 & 8.71 & -30.32 \\
\hline Stretch-bend & 0.39 & 0.17 & -4.08 & 0.13 & 1.95 & 1.08 & -4.08 & 0.16 \\
\hline Electrostatic & 0 & 0 & 0 & 0 & 0 & 0.00036 & 0 & 0 \\
\hline E binding & -12.58 & 12.60 & 11.07 & -10.26 & -284.10 & -157.82 & 11.07 & -155.95 \\
\hline
\end{tabular}
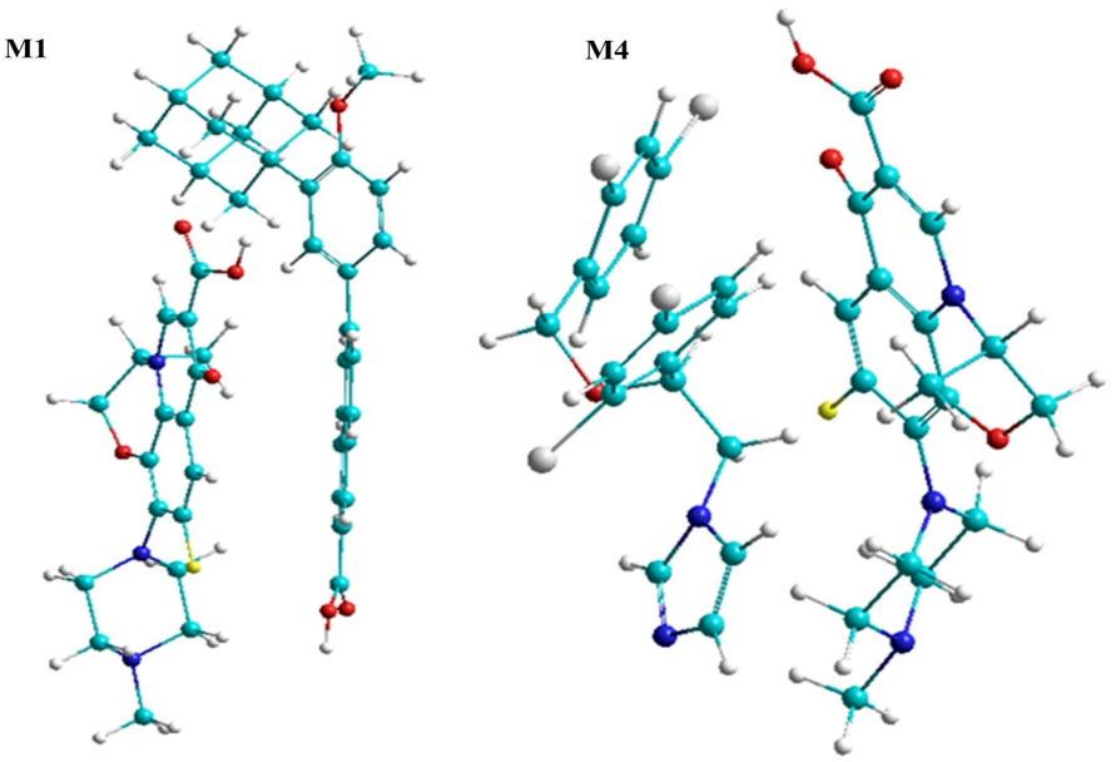

Figure 2.

The most stable conformations of M1 and M4

(legend of atoms: light blue $-\mathrm{C}$; dark blue $-\mathrm{N}$; red $-\mathrm{O}$; grey $-\mathrm{H}$; yellow $-\mathrm{F}$ )

Compatibility study by FTIR analysis

FTIR analysis is a sensitive spectroscopic technique often used as a compatibility screening. The vibrational changes of registered spectra offer information regarding potential intermolecular interactions among the selected binary mixture of active substances. Advantages of FTIR spectroscopy comprise small samples size, detection of incompatibility (the shifts of unique bands), rapid data acquisition, availability of databases and accessibility of instruments [15].

The FTIR spectra of pure compounds and their binary mixtures (1:1 mass ratio) had been registered. The most relevant comparisons of FTIR spectra of active substances with the spectra of their mixtures are presented in Figure 3.

The FTIR spectra of the M1-M4 stored for one month in the refrigerator $\left(8^{\circ} \mathrm{C}\right)$ did not reveal any parameter changes.

$M 1$ vs. ADA and LEV. Regarding M1 FTIR spectra, the strongest band at $2901.38 \mathrm{~cm}^{-1}$ assigned to $\mathrm{OH}$ (carboxyl) stretching vibrations and $2848.35 \mathrm{~cm}^{-1}$, assigned to $\left(-\mathrm{CH}_{2}-\right)$ stretching vibrations of ADA [37], remained unchanged, while a particularly strong band of ADA spectra at $1686.44 \mathrm{~cm}^{-1}$ assigned to $\mathrm{C}=\mathrm{O}$ (carboxyl) stretching vibration [22, 60] slightly increased to $1689.34 \mathrm{~cm}^{-1}$, in the mixture with LEV. The band at $1236.15 \mathrm{~cm}^{-1}$ assigned to R-O-Ar (aromatic ether) appears as comprised in the band at $1240.97 \mathrm{~cm}^{-1}$ of LEV spectra, which is assigned to R-O-R (ether) [77]. Thus, on LEV spectra the peaks at $2973.7 \mathrm{~cm}^{-1}$, $2936.09 \mathrm{~cm}^{-1}$ and $2802.06 \mathrm{~cm}^{-1}$, assigned to $\mathrm{C}-\mathrm{H}$ stretching vibrations of methyl radical at the N4' nitrogen atom in the piperazinyl moiety [20] remain unchanged in the mixture with ADA. The band at $1453.1 \mathrm{~cm}^{-1}$, assigned to $\delta\left(\mathrm{CH}_{3}\right)$ and $\mathrm{C}=\mathrm{C}$ stretching aromatic ring [26, 77], also appeared unchanged, while the absorption band at $1135.87 \mathrm{~cm}^{-1}$, assigned to $\delta(\mathrm{OH})$ [77], was slightly shifted to $1134.9 \mathrm{~cm}^{-1}$. A strong absorption band at $1089.58 \mathrm{~cm}^{-1}$ assigned to R-O-R [54] moiety of LEV was not shifted in the M1 spectra. In fact, the characteristic bands of both ADA and LEV were not changed significantly in their mixture - M1. 


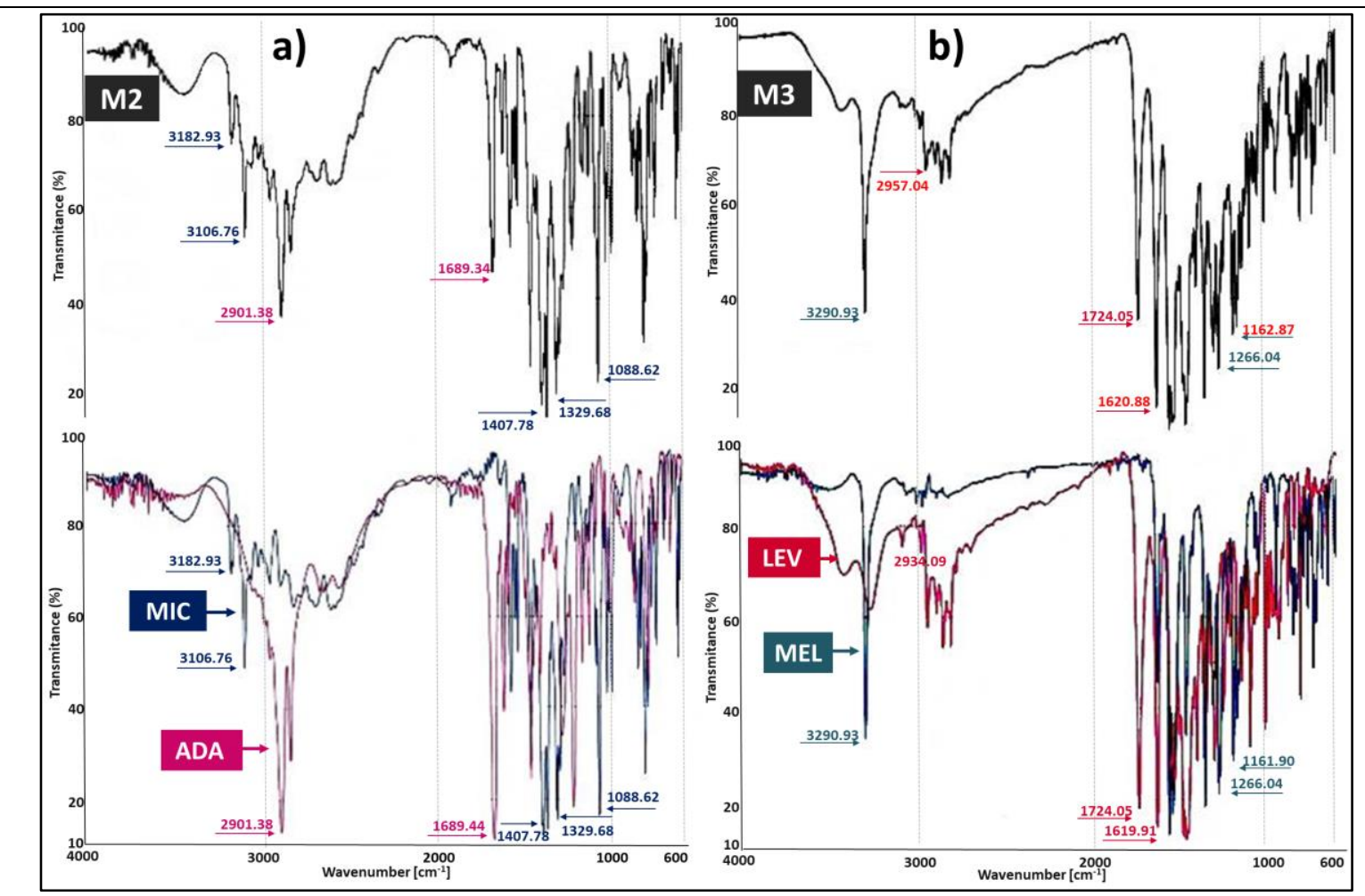

Figure 3.

Examples of recorded FTIR spectra of M - mass ratio 1: 1 in binary mixtures (above) and the overlay spectra of their individual compounds (below): a) M2 and ADA/MIC spectra; b) M3 and LEV/MEL spectra

M2 vs. ADA and MIC (Figure 3a). All the characteristic registered frequencies of ADA spectra were not changed in the $\mathrm{M} 2$ spectra, except for the band at $1686.44 \mathrm{~cm}^{-1}$, assigned to $\mathrm{C}=\mathrm{O}$ (carboxyl) stretching vibration $[22$, $54,60]$ which was slightly increased to $1689.34 \mathrm{~cm}^{-1}$. Also, there were no changes regarding significant bands of MIC spectra in its mixture with ADA. The bands at $3182.93 \mathrm{~cm}^{-1}$ assigned to $\mathrm{C}-\mathrm{N}$ imidazole stretch vibration and $3106.76 \mathrm{~cm}^{-1}$ assigned to $\mathrm{C}-\mathrm{H}$ aromatic stretching vibration $[38,67]$ were not shifted. Other registered bands of MIC spectra were at 1588.09 $\mathrm{cm}^{-1}, 1561.09 \mathrm{~cm}^{-1}$ and $1546.6 \mathrm{~cm}^{-1}$ assigned to C-C stretching vibration and $\mathrm{C}=\mathrm{C}$ aromatic vibration; $1475.28 \mathrm{~cm}^{-1}$ assigned to $\mathrm{C}-\mathrm{H}$ stretching vibration; $1329.68 \mathrm{~cm}^{-1}$ assigned to $\mathrm{C}-\mathrm{N}$ stretching vibration; $1171.54 \mathrm{~cm}^{-1}$ assigned to $\mathrm{C}-\mathrm{O}$ stretching vibration, and $1015.34 \mathrm{~cm}^{-1}$ assigned to $\mathrm{C}-\mathrm{C}$ stretching vibration $[5,38,67,80,89]$. Also, the strong absorption band at $1088.62 \mathrm{~cm}^{-1}$ assigned to the aliphatic ether moiety of MIC has remained unchanged, as well as the band at $637.358 \mathrm{~cm}^{-1}$ assigned to $\mathrm{C}-\mathrm{Cl}$ vibration $[54,61,67]$. Only a slight shift occurred from $2961.16 \mathrm{~cm}^{-1}$ (MIC spectra) to $2962.13 \mathrm{~cm}^{-1}$ (M2 spectra), which can be assigned to $\mathrm{C}-\mathrm{H}$ aliphatic stretching vibration $(\mathrm{C} 2$ spectra) $[38,67]$. Thereby, it can be considered that the FTIR spectra of ADA and MIC did not change significantly in their mixture - M2.

$M 3$ vs. LEV and MEL (Figure $3 b$ ). The FTIR bands of LEV in its mixture with MEL presented several slight shifts when compared to the bands of LEV spectra. For example, the band at $2936.09 \mathrm{~cm}^{-1}$ and $2847.38 \mathrm{~cm}^{-1}$, assigned to $\mathrm{C}-\mathrm{H}$ stretching vibrations of methyl radical at the $\mathrm{N}^{4}$ nitrogen atom in the piperazinyl moiety [20], was slightly shifted to 2937.06 $\mathrm{cm}^{-1}$ and $2848.35 \mathrm{~cm}^{-1}$ in M3 spectra. Thus, the significant bands of LEV spectra were not influenced by combination with MEL. Also, in the spectra of M3, several slight shifts of MEL characteristic frequencies occurred. The most representative shifts were from $1456.96 \mathrm{~cm}^{-1}$ to $1455.99 \mathrm{~cm}^{-1}(\delta(\mathrm{CH} 3)), \mathrm{C}=\mathrm{C}$ stretching aromatic ring), $1347.03 \mathrm{~cm}^{-1}$ to $1346.07 \mathrm{~cm}^{-1}$ and 1161.9 $\mathrm{cm}^{-1}$ to $1162.87 \mathrm{~cm}^{-1}$ ( $\mathrm{S}=\mathrm{O}$ stretching vibration), $1044.26 \mathrm{~cm}^{-1}$ to $1046.19 \mathrm{~cm}^{-1}$ (aromatic C-H vibration), and $714.497 \mathrm{~cm}^{-1}$ to $713.533 \mathrm{~cm}^{-1}$ (aliphatic $\mathrm{C}-\mathrm{H}$ vibration) [26, 77, 94]. Overall, however, it may be considered that the FTIR spectra of LEV and MEL were not changed significantly in their mixture M3. M4 vs. LEV and MIC. A band at $2936.09 \mathrm{~cm}^{-1}$ in LEV spectra assigned to $\mathrm{C}-\mathrm{H}$ stretching vibrations of methylene groups in $\mathrm{R}-\mathrm{O}-\mathrm{Ar}\left(3000-2700 \mathrm{~cm}^{-1}\right)$ [20] were slightly shifted to $2937.06 \mathrm{~cm}^{-1}$, in the mixture with MIC. The characteristic band of LEV spectra at $1724.05 \mathrm{~cm}^{-1}$ assigned to $(\mathrm{C}=\mathrm{O})$ carboxyl stretching vibrations [20] were not influenced by combination with MEL. Similarly, the band at 1619.91 $\mathrm{cm}^{-1}$ assigned to $(\mathrm{C}=\mathrm{O})$ pyridone stretching vibrations [20] was also slightly shifted to $1620.88 \mathrm{~cm}^{-1}$. The bands of MIC spectra did not change in combination with LEV, except the characteristic band at $1329.68 \mathrm{~cm}^{-1}$ assigned to $\mathrm{C}-\mathrm{N}$ stretching vibration $[38,67,89]$ 
FARMACIA, 2020, Vol. 68, 5

which was slightly shifted to $1331.61 \mathrm{~cm}^{-1}$. However, the characteristic bands of both LEV and MIC were not changed significantly in their mixture M4. Analysing the FTIR recorded data punctually for each compound of the samples, at each binary mixture, a common peak was identified with both components of the mixture, these being as follows: $1540.85 \mathrm{~cm}^{-1}-\mathrm{M} 1,1141.65$ $\mathrm{cm}^{-1}-\mathrm{M} 2,1619.91 \mathrm{~cm}^{-1}-\mathrm{M} 3$ and $963.27 \mathrm{~cm}^{-1}-\mathrm{M} 4$.
Also, it appears that the most significant changes determined in the mixtures occur in the regions of the 3900 to $2600 \mathrm{~cm}^{-1}$ frequencies (Figure 4), intervals for specific absorption and vibrations of -OH (alcoholfree or intermolecular bonded), $\mathrm{N}-\mathrm{H}$ (primary or secondary amine, amine salt), -OH from carboxylic acid (usually centred on $3000 \mathrm{~cm}^{-1}$ ), C-H (aldehyde) and S-H (thiol) $[15,54,80]$.

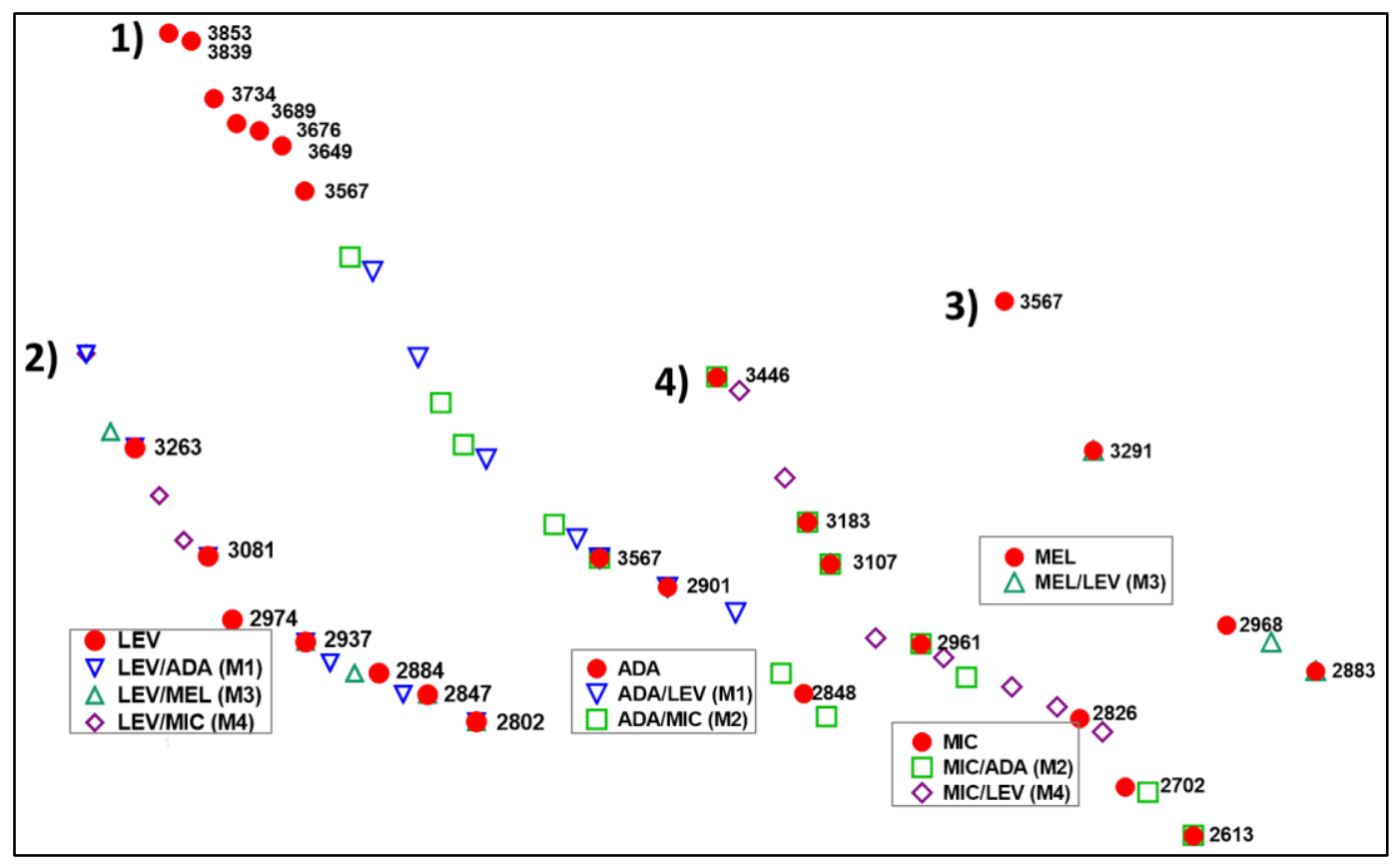

Figure 4.

The registered FTIR peaks $\left(\mathrm{cm}^{-1}\right)$ of individually compounds (1 - ADA, 2 - LEV, 3 - MEL and 4 - MIC) overlay on peaks of their binary mixtures $\left(1: 1\right.$ mass ratio), in the frequency regions of 3900 to $2600\left(\mathrm{~cm}^{-1}\right)$

Correlation of the results obtained by the MM and FTIR analyses

LEV and its binary mixtures. The data computed and calculated by MM showed that M1 (with ADA) and M4 (with MIC) have thermodynamically compatible chemical structures both in 1:1 molar ratio and in 1:1 mass ratio, as opposed to M3 (with MEL) in which the two components have potential for chemical interactions. These behaviours were confirmed by FTIR data.

$A D A, M I C, M E L$, and their binary mixtures. The data recorded by FTIR confirms that ADA has better compatibility in M1 (with LEV) than in M2 (with MIC); MIC shows better compatibility in M2 (with ADA) than in M4 (with LEV), and MEL (with LEV in M3) shows the weakest compatibility of all studied compounds. It should be noted that MIC was used in the form of nitrate (salt) anion which could explain the thermodynamic changes favourable to compatibility and highlight by $\mathrm{MM}$ in the case of $\mathrm{M} 2$ in 1:1 mass ratio versus $\mathrm{M} 2$ in 1:1 molar ratio.

Compatibility study by DSC analysis

The DSC is a thermal analysis method commonly used for the screening of incompatibilities between active substances to be included in pharmaceutical formulations [15, 29, 90]. This technique has several advantages such as being a rapid method that requires a small amount of sample, which allows simple detection of physical interactions (polymorphic form changes, crystalline to amorphous form conversion) [15].

The registered DSC curves are graphically presented in Figure 5. Analysed samples contained pure substances and physical mixtures in mass ratio 1:1. The DSC curves were analysed and compared in terms of MPs and changes in enthalpy (Table IV). If there is high compatibility of the compounds in the binary mixture, then a sum of the individual components is expected on the DSC curves of mixtures. On the contrary, incompatibility of components is related to the presence of significant shifts on MP values of the compound, the occurrence of a new peak (exo- or endothermic) and modification of enthalpies [15, 90].

$M 1$ vs. ADA and LEV (Figure 5a). DSC curve of LEV showed a dehydration process (endothermic transition) [34] also maintained in the mixture with ADA, which proves that the LEV sample is a hydrated compound. No significant changes were noticed until the mixture sample began to degrade at $217.93^{\circ} \mathrm{C}$ [72] similar to 
FARMACIA, 2020, Vol. 68, 5

another fluoroquinolone previously analysed [71]. The MP of LEV was slightly shifted from $227.72^{\circ} \mathrm{C}$, most probably characteristic to $\beta$ anhydrous crystallisation form [34], to $224.66^{\circ} \mathrm{C}$. Although the DSC curve of ADA did not show any phase transition peak until $328.28^{\circ} \mathrm{C}$ (MP), in mixture with LEV, several peaks appeared between $280-350^{\circ} \mathrm{C}$ and the MP was the probably shifted to $300.27^{\circ} \mathrm{C}$. This modification of
M1 - DSC curve shape could be attributed to possible hydrogen bonds between the $-\mathrm{COOH}$ groups of both compounds (ADA and LEV), decarboxylation processes, and a degradation process at high temperature. All these can be considered significant changes in the thermal behaviour in the mixture M1, compared to the pure ADA and LEV.

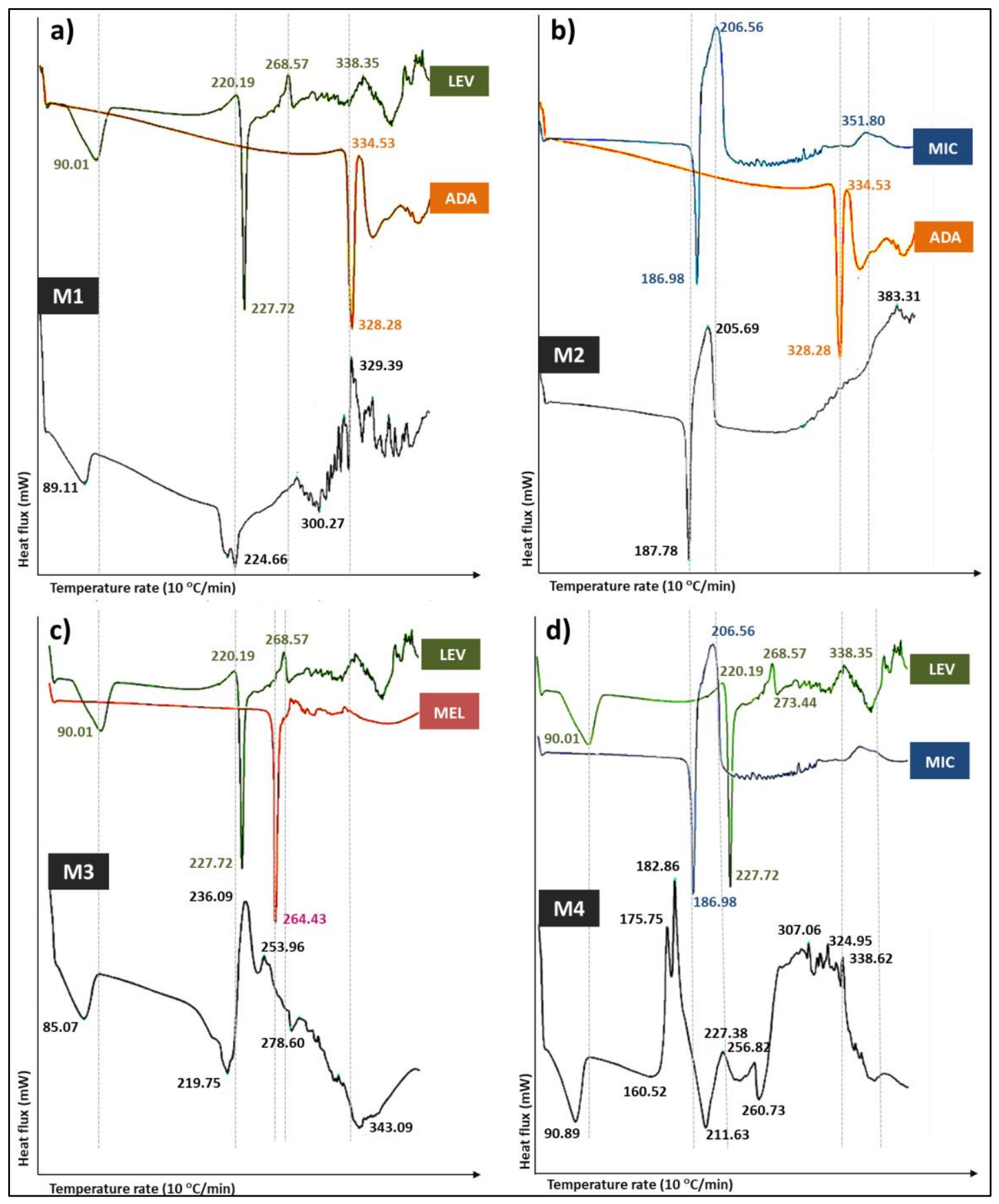

Figure 5.

DSC curves of M1-M4 1: 1 mass ratio binary mixtures (below) and their individually analysed compounds (above): a) M1 and ADA/LEV; b) M2 and ADA/MIC; c) M3 and LEV/MEL; d) M4 and LEV/MIC

M2 vs. ADA and MIC (Figure 5b). The DSC curve of $\mathrm{M} 2$ is very similar to the DSC curve of MIC, with no
ADA characteristic properties registered. The recorded MP value of MIC was $186.98^{\circ} \mathrm{C}$ [27]. In M2 the MP 
FARMACIA, 2020, Vol. 68, 5

of MIC was slightly shifted to $187.98^{\circ} \mathrm{C}$. A recent thermal study highlights that the MIC molecules cannot be involved in hydrogen bonds and show high glassforming ability and also high glass stability [68]. An aspect of the two DSC curves of binary mixtures with ADA (M1 and M2) was that the characteristic properties of ADA were not cumulated on DSC curves of mixtures with LEV or MIC. As an excipient can solubilise an active substance [19], probably a similar phenomenon was possible on M1 and M2 mixtures. The ADA-peaks disappearance in both mixtures can be explained by thermally induced drug-drug interaction or dissolution of ADA in the melted LEV or MIC during the DSC scan [53].
M3 vs. LEV and MEL (Figure 5c). The DSC curve of M3 recorded many changes compared to the pure compounds. Thus, both substances had shifted MPs, LEV from $227.72^{\circ} \mathrm{C}$ [34] to $219.65^{\circ} \mathrm{C}$ and MEL from $264.43^{\circ} \mathrm{C}$ to $278.60^{\circ} \mathrm{C}$, represented by an endothermic peak with low amplitude [6]. In M3 there were possible interactions between - $\mathrm{COOH}$ group of $\mathrm{LEV}$ and secondary - NH- group of MEL, and also dipole forces may occur between fluorine-carbon of LEV and the hydroxyl-carbon bonds of MEL. These significant changes suggest the incompatibility of LEV and MEL in the mixture - M3, in the conditions of increasing temperature.

Table IV

Characteristics of the thermal behaviour determined in the samples analysed by DSC

\begin{tabular}{|c|c|c|c|c|c|c|c|c|c|}
\hline \multirow{2}{*}{\multicolumn{2}{|c|}{$\begin{array}{c}\text { DSC parameter } \\
0 \rightarrow 40 \mathrm{~min} ; 10^{\circ} \mathrm{C} / \mathrm{min} \text { rate } \\
\end{array}$}} & \multicolumn{4}{|c|}{ a) Individual compound } & \multicolumn{4}{|c|}{ b) Binary mixture (1:1 mass ratio) } \\
\hline & & \multirow{2}{*}{$\begin{array}{c}\text { ADA } \\
-3.8\end{array}$} & \multirow{2}{*}{$\begin{array}{c}\text { LEV } \\
-0.6\end{array}$} & \multirow{2}{*}{$\begin{array}{c}\text { MEL } \\
-3.4\end{array}$} & \multirow{2}{*}{$\frac{\text { MIC }}{-}$} & \multirow{2}{*}{ M1 } & \multirow{2}{*}{$\begin{array}{l}\text { M2 } \\
2.4\end{array}$} & \multirow{2}{*}{$\begin{array}{l}\text { M3 } \\
-4.3\end{array}$} & \multirow{2}{*}{$\begin{array}{l}\text { M4 } \\
-3.5\end{array}$} \\
\hline Signal difference & $\mathrm{mW}$ & & & & & & & & \\
\hline \multirow{2}{*}{ Heat } & $\mathrm{J}$ & -1.2 & -3.5 & -3.3 & -1.7 & -4.7 & -4.7 & -2.1 & -1.7 \\
\hline & $\mathrm{kJ} / \mathrm{g}$ & -386.1 & -1.1 & -1.1 & -580.5 & -1.5 & -1.6 & -708.3 & -566.7 \\
\hline Peak & ${ }^{\circ} \mathrm{C}$ & 328.2 & 227.7 & 264.4 & 186.9 & 224.6 & 142.0 & 343.0 & 182.8 \\
\hline \multirow[t]{2}{*}{ Peak height: } & $\mathrm{mV}$ & -29.2 & 19.3 & 21.9 & 15.8 & 18.01 & 14.5 & 29.7 & 12.9 \\
\hline & $\mathrm{mW}$ & -3.5 & -0.7 & -2.3 & -1.4 & -1.2 & 0.4 & -3.9 & -1.3 \\
\hline DSC peak & ${ }^{\circ} \mathrm{C}$ & 320.2 & 227.7 & 264.4 & 186.9 & 224.6 & 187.7 & 343.0 & 182.8 \\
\hline Onset & ${ }^{\circ} \mathrm{C}$ & 324.9 & 226.1 & 262.8 & 184.8 & 49.3 & 184.9 & 53.5 & 57.4 \\
\hline Endset & ${ }^{\circ} \mathrm{C}$ & 328.3 & 234.5 & 268.3 & 189.1 & 328.8 & 189.6 & 226.4 & 171.5 \\
\hline \multirow[t]{2}{*}{ Heat } & $\mathrm{J}$ & -1.2 & -3.5 & -3.3 & -1.7 & -4.8 & -4.7 & -2.1 & -1.7 \\
\hline & $\mathrm{kJ} / \mathrm{g}$ & -386.1 & -1.2 & -1.1 & -580.5 & -1.6 & -1.6 & -708.3 & -566.7 \\
\hline \multirow[t]{2}{*}{ Glass Transition: } & $\mathrm{mW}$ & -3.8 & -0.6 & -3.5 & -2.3 & -2.1 & 2.4 & -4.3 & -3.5 \\
\hline & $\mathrm{mW} / \mathrm{min}$ & -1.2 & -0.2 & -1.2 & -0.8 & -0.7 & 0.8 & -1.4 & -1.1 \\
\hline Onset & ${ }^{\circ} \mathrm{C}$ & 324.9 & 226.1 & 262.8 & 184.8 & 49.2 & 184.9 & 53.5 & 54.4 \\
\hline Endset & ${ }^{\circ} \mathrm{C}$ & 327.1 & 219.7 & 263.0 & 184.6 & 48.9 & 185.6 & 60.7 & 62.3 \\
\hline Mid-Point & ${ }^{\circ} \mathrm{C}$ & 326.1 & 39.8 & 262.3 & 184.5 & 48.9 & 185.3 & 57.8 & 60.2 \\
\hline
\end{tabular}

$\mathrm{M} 1=\overline{\mathrm{ADA}} / \mathrm{LEV} ; \mathrm{M} 2$ = ADA/MIC; M3 = LEV/MEL; M4 = LEV/MIC

M4 vs LEV and MIC (Figure 5, d). DSC curve of M4 also recorded a dehydration process and several changes of properties of the two compounds in the mixture. Exothermic events (new strong peaks at $175.75^{\circ} \mathrm{C}$ and $182.86^{\circ} \mathrm{C}$ ) occur probably due to the hydrogen bonds between the hydroxyl/carboxyl group (LEV) and chlorine atoms (MIC). Also, there are possible dipole forces that may occur between fluorine-carbon (LEV) and chlorine-carbon bonds (MIC). The MP value of MIC $\left(182.98^{\circ} \mathrm{C}\right)$ was probably shifted to $211.63^{\circ} \mathrm{C}$. Over $300^{\circ} \mathrm{C}$, a decarboxylation event (LEV) and the decomposition of the sample may also appear. Although DSC curves of MIC showed only minor modifications in several mixtures with different excipients [2], MIC has dramatically changed, suggesting an incompatibility with LEV, based on the DSC of M4.

\section{Conclusions}

The therapeutic compounds LEV, ADA and MIC associated in binary 1:1 mass mixtures (M1, M2 and M4) proved to be compatible, in contrast to MEL in mixture with LEV (M3), by FTIR analyses method.
These experimental findings confirm the predictions of the mechanical-chemical compounds molecular compatibility calculated by molecular modelling, expressed in terms of thermodynamic binding energy which generates the ability of the associated compounds to form molecular complexes in binary mixtures. The used computational method is able to generate data closer to the experimentally measured ones, especially for $1: 1$ mass ratios binary mixtures, than for $1: 1$ molar ratio.

The thermal behaviour during DSC proved that different chemical interactions occur as the temperature rises above $160{ }^{\circ} \mathrm{C}$, especially for LEV associated with MEL (M3) and with MIC (M4).

The binary combinations ADA/LEV, ADA/MIC and LEV/MIC, could be considered as therapeutic ingredients for systems with dermal and/or transdermal delivery, prepared in the form of bio-adhesive dermal films produced by techniques that do not use or use moderate heat, such as the casting solvent evaporation technique. 


\section{Acknowledgement}

This work was supported by the George Emil Palade University of Medicine, Pharmacy, Science and Technology of Târgu Mureș, under Internal Research Grant contract no. 275/6/11.01.2017.

\section{Conflict of interest}

The authors declare no conflict of interest.

\section{References}

1. Ahmad I, Bano R, Sheraz MA, Ahmed S, Mirza T, Ansari SA, Photodegradation of levofloxacin in aqueous and organic solvents: a kinetic study. Acta Pharm., 2013; 63(2): 223-229.

2. Ahmed TA, El-Say KM, Mahmoud MF, Samy AM, Badawi AA, Miconazole nitrate oral disintegrating tablets: In vivo performance and stability study. AAPS Pharm SciTech., 2012; 13(3): 760-771.

3. Al Hanbali OA, Khan HMS, Sarfraz M, Arafat M, Ijaz S, Hameed A, Transdermal patches: Design and current approaches to painless drug delivery. Acta Pharm., 2019; 69(2): 197-215.

4. Bachhav YG, Patravale VB, Formulation of meloxicam gel for topical application: In vitro and in vivo evaluation. Acta Pharm., 2010; 60(2): 153-163.

5. Barillaro V, Dive G, Ziémons E, Bertholet P, Evrard B, Delattre L, Piel G, Theoretical and experimental vibrational study of miconazole and its dimers with organic acids: application to the IR characterization of its inclusion complexes with cyclodextrins. Int $J$ Pharm., 2008; 350(1-2): 155-165.

6. Bashiri-Shahroodi A, Nassab PR, Szabó-Révész P, Rajkó R, Preparation of a solid dispersion by a dropping method to improve the rate of dissolution of meloxicam. Drug Dev Ind Pharm., 2008; 34(7): 781-788.

7. Beale JM, Block GH, Wilson\&Gisvold`s Textbook of Organic Medicinal and Pharmaceutical Chemistry, Lippincott Williams Wilkins, Philadelphia, 2010; 980.

8. Bhalekar MR, Pokharkar V, Madgulkar A, Patil N, Preparation and evaluation of miconazole nitrateloaded solid lipid nanoparticles for topical delivery. AAPS Pharm SciTech., 2009, 10(1): 289-296.

9. Bhatia G, Zhou Y, Banga AK, Adapalene microemulsion for transfollicular drug delivery. J Pharm Sci., 2013; 102(8): 2622-2631.

10. Bîrsan M, Apostu M, Todoran N, Antonoaea P, Rusu A, Ciurba A, Development of dermal films containing miconazole nitrate. Molecules, 2018; 23(1640): 1-12.

11. Bîrsan M, Cristofor A.C, Antonoaea P, Todoran N, Bibire N, Panainte AD, Vlad RA, Grigore M, Ciurba A, Evaluation of miconazole nitrate permeability through biological membrane from dermal systems. Farmacia, 2020; 68(1): 111-115.

12. Bornare SS, Aher SS, Saudagar RB, A review: Film forming gel novel drug delivery system. Int J Curr Pharm Res., 2018; 10(2): 25-28.

13. Brunton LL, Chabner BA, Knollmann BC, Goodman \& Gilman's The Pharmacological Basis of Therapeutics, $12^{\text {th }}$ Edition, McGraw-Hill Education, New York 2011; 1571-1591.
14. Budavari S, The Merck index: an encyclopedia of chemicals, drugs, and biologicals, Merck, Whitehouse Station, New Jersey, 1996; 894.

15. Chadha R, Bhandari S, Drug-excipient compatibility screening-Role of thermoanalytical and spectroscopic techniques. J Pharm Biomed Anal., 2014; 87: 82-97.

16. Chen J, Gao Y, Strategies for meloxicam delivery to and across the skin: a review. Drug Deliv., 2016; 23(8): 3146-3156

17. Chu KA, Yalkowsky SH, An interesting relationship between drug absorption and melting point. Int $J$ Pharm., 2009; 373(1-2): 24-40.

18. Cuenca-Estrella $\mathrm{M}$, Combinations of antifungal agents in therapy - what value are they?. J Antimicrob Chemother., 2004; 54(5): 854-869.

19. da Silveira LM, Fiorot AB, Xavier TP, Yoshida MI, de Oliveira MA, Drug-excipient compatibility assessment of solid formulations containing meloxicam. Eur $J$ Pharm Sci., 2018; 112: 146-151.

20. Dorofeev VL, Arzamastsev AP, Veselova OM, Melting point determination for the analysis of drugs of the fluoroquinolone group. Pharm Chem J., 2004; 38(6): 333-335.

21. DrugBank. Release 5.1.4. (Canada): Canadian Institutes of Health Research (www.drugbank.ca).

22. Dubey A, Prabhu P, Kabrawala H, Ghate V, Niosomal gel of adapalene: its formulation, physicochemical properties and evaluation for mild-acne. Adv Biomed Pharma., 2015; 2(1): 22-31.

23. DuBois J, Ong GCW, Petkar G, Almeida LMC, Chavda R, Kerrouche N, Alexis AF, Patient-reported outcomes in acne patients with skin of color using adapalene $0.3 \%$-benzoyl peroxide $2.5 \%$ : A prospective real-world study. J Drugs Dermatol., 2019; 18(5): 514.

24. Dumka VK, Singh H, Srivastava AK, Disposition kinetics and urinary excretion of levofloxacin on concomitant administration with meloxicam in crossbred calves. Environ Toxicol Pharmacol., 2008; 26(1): 56-60.

25. El-Badry M, Physicochemical characterization and dissolution properties of meloxicam-Gelucire 50/13 binary systems. Sci Pharm., 2011; 79(2): 375-386.

26. Elbary AA, Ali AA, Aboud HM, Enhanced dissolution of meloxicam from orodispersible tablets prepared by different methods. Bull Fac Pharm (Cairo Univ), 2012; 50: 89-97.

27. European Pharmacopoeia Commission \& Council of Europe. European Pharmacopoeia $9^{\text {th }}$ edition. Council of Europe, Strasbourg, 2010; 1646, 2994, 3066.

28. Fatemi F, Najafian J, Nasab SS, Nilforoushzadeh MA, Treatment of acne vulgaris using the combination of topical erythromycin and miconazole. Skin Stem Cell, 2014; 1(3): 1-3.

29. Feist M, Thermal analysis: Basics, applications, and benefit. Chem Texts, 2015; 1(8): 1-12.

30. Feneran AN, Kaufman WS, Dabade TS, Feldman SR, Retinoid plus antimicrobial combination treatments for acne. Clin Cosmet Investig Dermatol., 2011; 4: 79-92.

31. Fish DN, Chow AT, The clinical pharmacokinetics of levofloxacin. Clin Pharmacokinet, 1997; 32(2): 101-119.

32. Flagothier C, Vroome V, Borgers M, Wang X, Cauwenbergh G, Piérard GE, Effect of a single 
overnight topical application of miconazole nitrate paste on acne papules. Int J Dermatol., 2006; 45(3): 316-319.

33. Gaikwad AK, Transdermal drug delivery system: Formulation aspects and evaluation. Compr J Pharm Sci., 2013; 1(1): 1-10.

34. Gorman EM, Samas B, Munson EJ, Understanding the dehydration of levofloxacin hemihydrate. J Pharm Sci., 2012; 101(9): 3319-3330.

35. Gratieri T, Alberti I, Lapteva M, Kalia YN, Next generation intra- and transdermal therapeutic systems: using non- and minimally-invasive technologies to increase drug delivery into and across the skin. Eur J Pharm Sci., 2013; 50(5): 609-622.

36. Grillon A, Schramm F, Kleinberg M, Jehl F, Comparative activity of ciprofloxacin, levofloxacin and moxifloxacin against Klebsiella pneumoniae, Pseudomonas aeruginosa and Stenotrophomonas maltophilia assessed by minimum inhibitory concentrations and time. Kill Studies, 2017; 22(6): 1-10.

37. Guo C, Khengar, RH, Sun M, Wang Z, Fan A, Zhao $\mathrm{Y}$, Acid-responsive polymeric nanocarriers for topical adapalene delivery. Pharm Res., 2014; 31(11): 30513059.

38. Gupta A, Kar HK, Solid state compatibility studies of miconazole using thermal and spectroscopic methods. Adv Analyt Chem., 2015; 5(3): 51-55.

39. Hori S, Kizu J, Kawamura M, Effects of antiinflammatory drugs on convulsant activity of quinolones: a comparative study of drug interaction between quinolones and anti-inflammatory drugs. $J$ Infect Chemother., 2003, 9(4): 314-320.

40. HyperChem (TM) Release 8.0, Tools for molecular modeling, Hypercube, Inc. Gainesville, Florida, USA, 2002.

41. Jackson MA, Gordon ES, Committee on Infectious Diseases, The use of systemic and topical fluoroquinolones. Pediatrics, 2016; 138(5): 1-15.

42. Jagdale S, Pawar S, Gellified emulsion of ofloxacin for transdermal drug delivery system. Adv Pharm Bull., 2017; 7(2): 229-239.

43. Jain N, Yalkowsky SH, Estimation of the aqueous solubility I: application to organic nonelectrolytes. J Pharm Sci., 2001; 90(2): 234-252.

44. Jakeer Hassan SK, Meena T, Lakshmi Durga T, Shahanaj SK, Formulation and evaluation of levofloxacin ointment. IJPSR, 2015; 6(7): 3067-3075.

45. Jawalkar SS, Raju KV, Halligudi SB, Sairam M, Aminabhavi TM, Molecular modeling simulations to predict compatibility of poly(vinyl alcohol) and chitosan blends: a comparison with experiments. $J$ Phys Chem B, 2007; 111(10): 2431-2439.

46. Jiang Q, Wang J, Ma P, Liu C, Sun M, Sun Y, He $\mathrm{Z}$, Ion-pair formation combined with a penetration enhancer as a dual strategy to improve the transdermal delivery of meloxicam. Drug Deliv Translat Res., 2018; 8(1): 64-72.

47. Kauffman CA, Carver PL, Use of azoles for systemic antifungal therapy. Adv Pharmacol., 1997; 39: 143-190.

48. Kawada A, Wada T, Oiso N, Clinical effectiveness of once-daily levofloxacin for inflammatory acne with high concentrations in the lesions. J Dermatol., 2012; 39(1): 94-96.
49. Keating G.M, Levofloxacin $0.5 \%$ ophthalmic solution: a review of its use in the treatment of external ocular infections and in intraocular surgery. Drugs, 2009; 69(9): 1267-1286.

50. Khan AM, Rampal S, Sood NK, Effect of repeated oral administration of levofloxacin, enrofloxacin, and meloxicam on antioxidant parameters and lipid peroxidation in rabbits. Hum Exp Toxicol., 2017; 36(1): 42-50.

51. Levofloxacin. Tuberculosis, 2008; 88(2): 119-121.

52. Mao F, Kong Q, Ni W, Xu X, Ling D, Lu Z, Li J, Melting point distribution analysis of globally approved and discontinued drugs: A research for improving the chance of success of drug design and discovery. ChemistryOpen, 2016; 5(4): 357-368.

53. Medarevic DP, Kachrimanis K, Mitric M, Djuris J, Djuric Z, Ibric S, Dissolution rate enhancement and physicochemical characterization of carbamazepinepoloxamer solid dispersions. Pharm Dev Technol., 2015; 21(3): 268-276.

54. Mistry BD, $A$ Handbook of spectroscopic data chemistry (UV, IR, PMR, 13CNMR and Mass Spectroscopy), Oxford Book Company, Jaipur, 2009.

55. Moffat AC, Clarke's Isolation and Identification of Drugs, The Pharmaceutical Press, London, 1989; 784.

56. Morales JO, Brayden DJ, Buccal delivery of small molecules and biologics: of mucoadhesive polymers, films, and nanoparticles. Curr Opin Pharmacol., 2017; 36: 22-28.

57. Münch S, Wohlrab J, Neubert RHH, Dermal and transdermal delivery of pharmaceutically relevant macromolecules. Eur J Pharm Biopharm., 2017; 119: 235-242.

58. Ndesendo V, Pillay V, Choonara EY, Toit L, Kumar P, Buchmann E, Meyer L, Khan AR, Optimization of a polymer composite employing molecular mechanic simulations and artificial neural networks for a novel intravaginal bioadhesive drug delivery device. Pharm Dev Technol., 2012; 17(4): 407-420.

59. Ochi M, Kimura K, Kanda A, Kawachi T, Matsuda A, Yuminoki K, Hashimoto N, Physicochemical and pharmacokinetic characterization of amorphous solid dispersion of meloxicam with enhanced dissolution property and storage stability. AAPS PharmSciTech., 2016; 17(4): 932-939.

60. Pajić NZB, Todosijević MN, Vuleta GM, Cekić ND, Dobričić VD, Vučen SR, Čalija BR, Lukić MŽ, Ilić TM, Savić SD, Alkyl polyglucoside vs. ethoxylated surfactant-based microemulsions as vehicles for two poorly water-soluble drugs: physicochemical characterization and in vivo skin performance. Acta Pharm., 2017; 67(4): 415-439.

61. Parashar B, Kabra A, Chandel A, Formulation and evaluation of gel containing miconazole nitrate an antifungal agent. Int J Pharma Res Rev., 2013; 2(6): 18-28.

62. Pastore MN, Kalia YN, Horstmann M, Roberts MS, Transdermal patches: history, development and pharmacology. Br J Pharmacol., 2015; 172(9), 21792209.

63. Pathak D, Dahiya S, Pathak K, Solid dispersion of meloxicam: factorially designed dosage form for geriatric population. Acta Pharm. 2008; 58(1): 99-110. 
64. Pérez-Sánchez H, Bioinformatics. InTech Open Access Publisher, Madrid, 2012; 185-212.

65. Petrou MA, Rogers TR, In-vitro activity of antifungal agents in combination with four quinolones. Drugs Exp Clin Res., 1988; 14(1): 9-18.

66. Prajapati SK, Kumar S, Singh A, Singh A, Development and characterization of topical microemulsion of levofloxacin. World J Pharm Pharm Sci., 2013; 2(6): 5935-5947.

67. Qushawy M, Nasr A, Abd-Alhaseeb M, Swidan S, Design, optimization and characterization of a transfersomal gel using miconazole nitrate for the treatment of candida skin infections. Pharmaceutics, 2018; 10(1): 1-22.

68. Ramos JJ, Diogo HP, The slow relaxation dynamics in active pharmaceutical ingredients studied by DSC and TSDC: Voriconazole, miconazole and itraconazole. Int J Pharm., 2016; 501(1-2): 39-48.

69. Riahifard N, Tavakoli K, Yamaki J, Parang K, Tiwari $\mathrm{R}$, Synthesis and Evaluation of Antimicrobial Activity of $\left[\mathrm{R}_{4} \mathrm{~W}_{4} \mathrm{~K}\right]$-Levofloxacin and $\left[\mathrm{R}_{4} \mathrm{~W}_{4} \mathrm{~K}\right]$-LevofloxacinQ. Molecules, 2017; 22(6): 1-11.

70. Romani L, Yoshida M, Gomes E, Machado R, Rodrigues F, Coelho M, Oliveira M, Freitas-Marques M, San Gil R, Mussel W, Physicochemical characterization, the Hirshfeld surface, and biological evaluation of two meloxicam compounding pharmacy samples. J Pharm Anal., 2017; 8(2): 103-108.

71. Rusu A, Hancu G, Toma F, Mare AD, Man A, Velescu BS, Uivarosi V, Synthesis, characterization and microbiological activity evaluation of two silver complexes with norfloxacin. Farmacia, 2016; 64(6): 922-932.

72. Sadeek SA, Mohammed SF, Rashid NG, Spectroscopic studies and thermal analysis of some new metal complexes with levofloxacin and glycine. J Chem Pharm Res., 2018; 10(3): 33-42.

73. Sardana K, Gupta T, Garg VK, Ghunawat S, Antibiotic resistance to Propionobacterium acnes: worldwide scenario, diagnosis and management. Expert Rev Anti Infect Ther., 2015; 13(7): 883-896.

74. Saroha KÂ, Yadav B, Sharma B, Transdermal patch: a discrete dosage form. Int J Curr Pharm Res., 2011; 3(3): 98-108.

75. Saxena A, Wong D, Diraviyam K, Sept D, The basic concepts of molecular modeling. Methods Enzymol., 2009; 467: 307-334.

76. Shacham S, Topf M, Avisar N, Glaser F, Marantz Y, Bar-Haim S, Noiman S, Naor Z, Becker OM, Modeling the 3D structure of GPCRs from sequence. Med Res Rev., 2001; 21(5): 472-483.

77. Shakhtshneider TP, Myz S.A, Dyakonova MA, Boldyrev VV, Boldyreva EV, Nizovskii AI, Kalinkin AV, Kumar R, Mechanochemical preparation of organicinorganic hybrid materials of drugs with inorganic oxides. Acta Phys Pol A, 2011; 120(2): 272-278.

78. Shroot B, Pharmacodynamics and pharmacokinetics of topical adapalene. J Am Acad Dermatol., 1998; 39(2 Pt 3): S17-24.

79. Shtanyuk YA, Analysis of antibacterial activity of ointments with levofloxacin and decametoxine on clinical strains agents of wound infections. World Med Biol., 2015; 52(3): 74-77.

80. Spectral Database for Organic Compounds SDBS, SDBSWeb: https://sdbs.db.aist.go.jp.

81. Sweetman SC, Martindale: The Complete Drug Reference, The Pharmaceutical Press, London, 2002; 384.

82. Takhulee A, Takahash Y, Molecular simulation and experimental studies of the miscibility of polylactic acid/polyethylene glycol blends. J Polym Res., 2017; 24(8): 81-89.

83. Takigawa M, Tokura Y, Shimada S, Furukawa F, Noguchi N, Ito T, Acne Study Group, Clinical and bacteriological evaluation of adapalene $0.1 \%$ gel plus nadifloxacin $1 \%$ cream versus adapalene $0.1 \%$ gel in patients with acne vulgaris. J Dermatol., 2013; 40(8): 620-625.

84. Tan J, Tanghetti E, Baldwin H, Stein Gold L, Lain E, The role of topical retinoids in prevention and treatment of atrophic acne scarring: Understanding the importance of early effective treatment. J Drugs Dermatol., 2016; 18(3): 255-260.

85. Todoran N, Antonoaea P, Rusu A, Ciurba A, Bîrsan M, Redai E, DSC and FT-IR analysis for the formulation of dermal films with meloxicam in bioadhesive polymeric matrix. Rev Chim (Bucharest), 2018; 69(12): 3692-3697.

86. Türck D, Roth W, Busch U, A review of the clinical pharmacokinetics of meloxicam. Br J Rheumatol., 1996; 35(1): 13-16.

87. Vijaya Kumar SG, Mishra DN, Preparation, characterization and in vitro dissolution studies of solid dispersion of meloxicam with PEG 6000. Yakugaku Zasshi, 2006; 126(8): 657-664.

88. Vizserálek G, Berkó S, Tóth G, Balogh R, BudaiSzücs M, Csányi E, Sinkó, B, Takács-Novák K, Permeability test for transdermal and local therapeutic patches using Skin PAMPA method. Eur J Pharm Sci., 2015, 76: 165-172.

89. Wang J, Zaisheng C, Investigation of inclusion complex of miconazole nitrate with $\beta$-cyclodextrin. Carbohydr Polym., 2008; 72(2): 255-260.

90. Wesołowski M, Analysis of drug formulations by thermal decomposition. Thermochim Acta, 1992; 209: 223-251.

91. Yotsumoto K, Ishii K, Kokubo M, Yasuoka S, Improvement of the skin penetration of hydrophobic drugs by polymeric micelles. Int J Pharm., 2018; 553(1-2): 132-140.

92. Yu J, Zhang Y, Kahkoska AR, Gu Z, Bioresponsive transcutaneous patches. Curr Opin Biotechnol., 2017;48: 28-32.

93. Yuan $\mathrm{X}, \mathrm{Xu} \mathrm{Y}$, Recent trends and applications of molecular modelling in GPCR-Ligand recognition and structure-Based drug design. Int J Mol Sci., 2018; 19(2105): 1-16.

94. Zaman M, Hanif M, Qaiser AA, Effect of polymer and plasticizer on thin polymeric buccal films of meloxicam designed by using central composite rotatable design. Acta Pol Pharm-Drug Res., 2016; 73(5): 1351-1360 